Milena Jokanović

\title{
Is there a potential of reaching (omni) knowledge in the digital space?
}

\section{A brief history of knowledge perception ${ }^{1}$}

001:004.1

DOI 10.18485/fdu dhkum.2021.ch16

There is nothing more divine than to know everything

(Plato)

The idea of gathering the whole knowledge of the world in one place is probably as old as humankind. The embodiment of it could still be found in a variety of collections: different literary concepts, museum collections, artworks, encyclopedias as well as many virtual creations. However, the concept of knowing everything and having at least one representative of each world's coating on the same spot has always been a utopian dream, an endless process in which there is at least some part of the puzzle lacking. Even though the human mind is still chasing this dream, it definitely seems less impossible in today's technologized world.

1 This paper is done as a result of the scientific activities of the Faculty of Philosophy, University of Belgrade, financed by the Ministry of Education, Science and Technological Development. A part of this research is conducted for the purposes of the doctoral thesis: Cabinets of Wonders in the Art World: The Use of Historical Models of Collecting in Contemporary Art World (Кабинети чудеса у свету уметности: употреба историјских модела музеализације у савременој уметничкој пракси) defended on June, 29th 2018 at the Art History Department, Faculty of Philosophy, University of Belgrade. 
In this paper, we will follow the genesis of different types of physical and literal collections that were imagined as micro cosmoses - images of the world, but we will also mention various individual scientific and creative projects that are trying to gather all the knowledge of the world in one place. Consequently, it will be very important to understand what the term 'to know' stands for in different eras. Nevertheless, the contemporary time and continuous development of information systems and digital humanities offer completely new ways of storing and classifying data in collections of digitized objects, giving as well new insights on how to use and combine them. Digital databases that are now being developed keep an enormous amount of information, while Artificial Intelligence manages to create those elements that are lost over time and missing. Therefore, we will also explore if the relationship towards knowledge has completely changed in the digital environment and if we are facing a new epistemological turn. Finally, we will come to the question if the all-encompassing collection of the world will finally be reached in contemporary time.

\section{The ancient urge to collect}

O God! I could be bounded in a nutshell, and count myself a King of infinite space

(Shakespeare, 1599)

The famous quoting from the Hamlet above, George Louis Borges has also borrowed for the beginning of his story on Aleph, a point in space that contains all other points. Anyone who would gaze into it could see everything in the Universe from every angle simultaneously, without distortion, overlapping, or confusion. This metaphor, even in fantastic literature, is actually revealing a great human will to know - to understand the world and gather it into one spot. A man would therefore be a sovereign of the Universe, the one owning a microcosm represented as a collection of various objects and understanding relations between them. 
When we think about the collection, the first association is often - a museum. However, this collection has its predecessors in a physical, as well as meaningful way. The term itself has its origin in the ancient Greek Movбєиоv - Mouseion relating to the temple dedicated to Muses, daughters of the Goddess of memory Mnemosyne and the supreme God Zeus. Linking a museum with systematic collecting and exploration of materials begins probably with Aristotle and his trips to the Lesbos Island in $340 \mathrm{BC}$, when in company with his pupil Theophrastus, he started accumulating, sorting, and studying botanical species. They continued the research in Lyceums, communities of scientists and students organized in order to systematically study biology, history, and other subjects. There was a Museion in every Lyceum, a place in which scientists could live, but also something like a cultural centre in which they were conducting all their research. It is consequently regarded that a Museion in Alexandria, one of the most famous institutions of classical antiquity, originates directly from the Aristoteles Museion. Actually, when Ptolomeus the First Soter tended to become the successor of Alexander the Great by fame, he established an institution similar to the Lyceum of Alexander's famous tutor Aristotle. "The work of museions involved the greatest minds of the ancient world, the editorial and cataloging activities established there changed the nature of Western education, while collections and libraries said to have numbered more than half a million top works - formed the basis for much of the classic literature that has outlived the demise of Greek civilization", sums up Jeffrey Abt. (Abt, 2014) Ivo Maroević will explain that: "The Museum of Alexandria, therefore, collects books (in the form in which they appeared then), minerals and natural rarities, has a botanical and zoo, stimulates reading and social life, is geared towards the study of literature, history, astronomy." On the other hand, numerous art collections are simultaneously formed in temples, so the paintings and reliefs in these collections illustrate the great poets, sculptors; they represent the development of art and its flourishing (Maroević, 1993: 18).

However, the period considered in the history of museology to be the beginning of the development of this heritage institution in the modern sense is certainly the Renaissance, as well as the 
development of humanistic thought and the desire to collect antiquities, ancient knowledge, and monuments, which were discovered and imitated or taken over, is considered extremely valuable and great. Paula Findlen explains the term musaeum as an epistemological structure that encompasses different ideas and institutions and links them to words that, as Popadić interpreted, meant

intellectual and philosophical categories, such as bibliotheca, thesaurus, or pandechion (meaning: all-encompassing), visual constructs such as cornucopia, gazophylacium (vault, palace or temple treasury), and spatial domains such as studio, casino, cabinet/gabinetto, galleria, theatro. In the proto-period of the museum, in the fifteenth, sixteenth and seventeenth centuries, collections of rarities (marvels, antiquities, and works of art) were housed in a private domain, in rooms called camerino, studietto, scrittoio (scriptoio), cabinetto (gabinetto), tesoro (tesoretto), guardaroba or antiquario (antiquarium). All these names signify, in different varieties, a workroom filled with precious objects. (Popadić, 2015: 88-89)

Collections of valuables were created by individuals and, through a multitude of objects, represented the personal universes of their owners, who always carefully selected objects. In this way, the collector became the subject of his own image of the world (Gnjatović, 2013).

\section{The idea of the Theatre of Knowledge}

In the same Renaissance period, the idea of creating a physical all-encompassing space in which the total collected knowledge of the world will be stored was represented in the work of Italian philosopher Giulio Camillo Delminio (1480-1544). Camillo reached worldwide fame during the sixteenth century for his literary constructions of a particular model of the Universe, a special kind of theatre, the Memory Theatre. As a circular wooden structure filled with significant words, pictures, objects, and their folders 
where each occupies a very specific position in the overall scheme, Camillo's Theatre reversed the traditional viewing model, placing objects where the audience in the amphitheater traditionally sat and positioning just one viewer on the stage. Camillo drew inspiration from ancient, especially classical, the vision of memory skills, inventing a physical installation that explored the relationship between the embodied and the abstract, vision and mind, looking and comprehending.

The Theatre is meant as a system of memory locations and, although „sublime and incomparably spaced“, it functions as a classic memory system for speakers by „storing the objects, words, and skills we have entrusted to it". In classical times, speakers housed parts of words they wanted to memorize in "passing places", while Camillo, "wanting to preserve for eternity the timely nature of all things that could be expressed through speaking", designates "eternal places" for them. Giulio Camillo talks about constructing an image of the world, and the greatness of his idea is that this is an invention of memory that is organically linked to the Universe (Yates, 1966).

Frances Yates will conclude that the missing wooden theatre, Camillo's Memory Theatre, is related to many aspects of the Renaissance precisely because it represents a new renaissance plan of the psyche, a change that has occurred within memory and served as a momentum for external change. The medieval man was allowed to use his imagination and form "bodily similarities" to foster memory; it was a concession to his lack of perfection. Yet, as Yates explains:

The Renaissance Hermetic man believes he has divine power; he can form a magic memory through which he grasps the world, reflecting the divine macrocosm in the microcosm of his divine mens. The magic of celestial proportion flows from his world memory into the magical words of his oratory and poetry, into the perfect proportions of his art and architecture. Something has happened within the psyche, releasing new powers, and the new plan of artificial memory may help us understand the nature of that inner event. (Yates, 1966, p. 172) 
Therefore, by now we could conclude that the will of a man to understand nature and all the happenings around was embodied through different types of collections of various objects and many attempts to memorize all the elements of the world. Early Modern Age and positioning of a human and his mind in the focus of attention, opens new horizons of this urge to know and collect that will develop and transform through time, having always the same goal. However, some concepts and ideas as for example the aboveexplained Memory Theatre will still be flowing through the limbo of civilization being just expressed through different media.

\section{"Cabinets of the World" in the Renaissance episteme}

It is an interesting question what the term to know stands for in different times, and how come that the idea of knowing and understanding is so closely connected to the activity of collecting. In 1992, Eliean Hooper - Greenhill wrote a very significant study, Museums and Shaping of Knowledge, in which she refers to Foucault's concept of episteme and relation to the notion and meaning of knowledge across different epochs, an idea that Michel Foucault presents in his capital work: The Order of Things: An Archaeology of the Human Sciences (original title: Les Mots et les choses [words and things], published in French in 1966, and in English in 1970). The concept of an episteme refers to a subconscious but positive and productive set of relationships within which knowledge is produced and rationality is defined. Foucault suggests that what counts in knowledge is always largely dependent on particular elements, including social, cultural, political, scientific, and others. These elements relate to each other or correspond to each other in a state of constant flux - flow, so that the meaning is also constantly defined and redefined. The elements themselves also vary over time, as for example "science" and "culture" change and redefine themselves. Certainly, within the consistent flow of meaning, Foucault recognizes a great coincidence in the intellectual activities of particular periods. This coincidence constituted through elements in 
relationships, forms the basis for identifying the episteme (Fuko, 1971). Hooper - Greenhill, through the epistemes that Foucault establishes, explains the relationship to collecting, and the creation of different collections from the Renaissance period and the so-called Renaissance episteme, through the Classical episteme, to the modern age. Each of these epistemes has rather specific characteristics and the change from one to the next represented a massive cultural and epistemological turnaround, devastation that meant complete rewriting/redefinition of knowledge.

The already discussed Renaissance period and the time of the creation of the first collections of various natural and artificial objects correspond to Foucault's Renaissance episteme. In this epoch, the world is a world of signs to be read, and the endless task of interpretation is the basic structure of knowledge. Similarities and identities are recognized on the surface of things and do not delve deeper into the core and modes of functioning. The magical and the occult were integral parts of knowledge. As a consequence of this endless re-reading, words and things are understood as the same. In fact, words were only used to define the material world. There were as many languages that referred to stones, animals, and plants as could be found in books. Writing and reading were activities of the privileged. Foucault describes the Renaissance episteme as plethoric but afflicted with poverty: unlimited because the similarities are never stable but consist of endless relationships. This was a knowledge that could, and indeed did, arise from accumulations of configurations that were all dependent one on another, but the "scientific" knowledge did not still exist. Collections of the time, cabinets of arts and wonders were organized following the particular categories and principles of the Art of Memory ${ }^{2}$ or visualizing the Memory Theatre (as we can conclude from the Studiolo of Francesco Medici decoration for example ${ }^{3}$ ).

2 In her book, quoted also in this paper, Frances Yates explains well how the Art of Memory functioned and how it was applied.

3 This topic is explored in detail in the work of Milosavljević - Ault (2005), Studiolo kao predmet istraživanja u istoriji umetnosti i istoriji kolekcionarstva. 
All these were attempts to gather the existing knowledge in one physical space.

The collection of objects during this period, or the "Cabinet of the World" as Hooper - Greenhill calls it, was a form of language, a material record of universal knowledge, and an image of the world. Knowledge consisted of connecting one language with another: of allowing everything to speak. The "Cabinet of the World" was therefore a form of language with a complex relation to other languages of the world. The encyclopedic project that Foucault identifies over the last few years of the sixteenth century has sought to forgive material knowledge according to cosmological structures, to reconstruct the order of the Universe in the way words and texts have been interconnected and arranged in space (Hooper - Greenhill, 1992).

Travels across the Ocean and great discoveries have broadened mental horizons as well. At the same time, the cosmology of the late Renaissance revised and occulted medieval magic knowledge. The world was divided into a macrocosm (representing God whose products were understood as Nature) and a microcosm of man, whose products, the objects he creates, are understood as art, that is, skill. The art world and the natural world were in constant oscillation, sometimes opposing each other and sometimes in symbiosis. As occult philosophers and others thought, art was an "imitation of nature" and thus represented in cosmological maps. Sharing art and nature, presenting microcosms and macrocosms has embodied new categories of objects in the collection: artificialia and naturalia (Hooper - Greenhill, 1992: 90).

The Renaissance episteme with basic characteristics of similarity between two objects, symmetry, and constant new cyclical interpretations helped us to understand what was actually considered knowledge at the time of the creation of the Curiosity Cabinets, id est. Wonders and similar collections of various objects, and how these represented a material record of universal knowledge. However, there were always some elements of the collection missing for the creation of the totality imagined by the creator. The constant abundance of some objects in the collection offers conclusions on the insatiable need to add, complete, collect, not to leave an empty 
place. It speaks to the cyclical nature of the desire to possess and the pleasure of owning, to the unfinished activity always in progress, to the never completed collection.

\section{Encyclopedic knowledge of the Classical episteme}

The concept of these wondrous collections began to change when differences became more important than correspondences (similarities). This will lead to the separation of categories of objects and their transfer to specialized institutions: naturalia to museums of natural history, and artificialia to art galleries. In the 18th century, Foucault recognized the great turn in relation to knowledge as a Classical episteme.

The Classical episteme set itself a much more restrictive project than the Renaissance. Its basic structure was ordered, through the measurement and establishment of hierarchical series. The activity of the mind, knowledge, no longer consisted in bringing all things together, but in separating them, discriminating on the basis of difference instead of adding on the basis of similarity. To know meant to separate, and this separation took place in two parts: on the one hand taxonomies and on the other endless natural resources that would serve man to analyze differences between species. Theory and nature, being and knowing, have become two sides of the world, now to be learned through objective analyzes rather than through subjective, personal experiences.

The Classical age rejected the complexity of the Renaissance episteme and during this period attempts were made to present simplified but highly verifiable knowledge. In the classification table, the order is represented by the visible characteristics of things (Hooper - Greenhill, 1992).

This form of cognition, however, also had its faults. It was proven that it is not possible to relate all things in the world to one another on the basis of visible differences in a large flat diversity table. Also, it was not possible to edit the language so that each word represents one element of the material world. For us today 
this seems pointless as an idea. We no longer understand language as one that will represent things. We 'know' that words represent thoughts. Language refers to the activities of the mind rather than the materiality of nature.

In an effort to unify knowledge of the world in one place, in one space, or on blank white pages - a tabula rasa that will remember over time the written knowledge from all fields, sciences, and disciplines - the Encyclopaedia was created. The desire to systematize knowledge, but also to edit the text, again is not much different from the memory space that was earlier described. Dalembert in the Introductory Debate in the Encyclopedia writes:

The encyclopedic order of our knowledge does not coincide with the historical one. It consists in gathering knowledge in the smallest possible space, and in placing the philosopher above this vast labyrinth, in a sublime view from which he can perceive both science and basic skills, at one glance to see the objects of their speculation and the actions he can perform with these objects, to distinguish between the general branches of human knowledge the points that separate them, and the points that connect them, and sometimes even anticipate the hidden paths that connect them. (Dalamber, 1995)

The physical division of objects, bearers of knowledge, and meaning is exactly what the Encyclopedia strives for, while the Philosopher, the god of this microcosm, stands like Camillo's spectator in the Theatre, in a sublime position and at one glance sees all objects. In his study of early modern collections and the media, Wolfgang Ernst points out the implications of this for the physical structure of the cabinet and the corporality of its collection. Originally understood as a "place for contemplation", it was possible for the "museum", as Ernst articulates it, to be "virtually without object [...] a cognitive field of ideas, words, and artefacts that are narrowed down to given meanings only in its institutional encryption and crystallization." Ernst believes that "long [...] the museum was not a place but a text, occupying a position in the discursive field" between the types of collections described by Paula Findlen (Ernst, 
2013). Thus, cabinets, museums, and encyclopedias are bound by the same idea, the pursuit of gathering omniscience, printing the text in palimpsest, and keeping the essence in a small space.

\section{Modern episteme and the turn back to the pictorial memory}

Foucault's modern episteme, after all, is based on the development of the human sciences. Human science exists where there are analyzes - within the dimension of the corresponding subconscious - of norms, rules, and semantic totals that reveal awareness of the conditions of these forms and contents. Human science is understood as a form of knowledge that only takes it as problematic and examines it. The reach of the modern episteme should be presented as a space open in three dimensions: deductive sciences such as mathematics and physics are in the first dimension, the sciences of language, life, and economics are placed in the second dimension, while the third dimension is a space for philosophical rethinking. Finally, the humanities, orbiting between these three, have succeeded in establishing themselves as the most characteristic way of knowing the modern age. Stories of man, life, and civilization will become much more significant than physical identities - appearances and material things. The basic structures of knowledge in the modern episteme are totality (story, theme, history, organic connections) and experience (relations between people and things, knowledge developed through the study of activities and empirical events). Knowing and knowledge have become three-dimensional, all-inclusive, and all-encompassing. The basic topics of knowledge are people, their lives, histories, and relationships (Hooper - Greenhill, 1992). Still, the attempts to create a particular Memory Theatre of the modern age are present, often using different media.

The development of technology and computer sciences encourages a man to look for new and extended spaces to preserve the memory of the world. Even though the World Wide Web was promising when thinking on one spot where all the information 
will be gathered, this global net is still missing the data or at least fails to organize them in a meaningful manner.

On the other hand, in his paper, Inventing Interfaces: Camillo's Memory Theatre and Renaissance of the Human-Computer Interaction, Peter Matussek writes about many different initiatives that are based on antique Ars Memoria and the Memory Theatre idea done in the last decade of the 20th and at the beginning of the 21st century.

To understand why it was the modern computer age, of all times, that created a favorable climate for Camillo's reception, we must recognize that both are characterized by a turn away from the culture of the book. Just as in the early era of the printed book Camillo turned away from its humanistic protagonists and, seemingly anachronistically, toward pictorial memory, so in its end phase did digitalization now create a 'cultural dispositive for visuality, new media, and postmodern narrativity' that, [...] established this fascination through $\mathrm{Ca}$ millo in the waning 20th century. Indeed, Marshall McLuhan's The Gutenberg Galaxy is already a swan song to the era of the printed book, which brought with it a linearization of thinking and a narrowing down of an earlier multimediality to normed typography. (Matussek, 2020: 59)

Consequently, a new, multimedia sphere offers a fruitful environment for projects of 3D models of the Memory Theatre, Virtual Reality applications for it, or the use of these concepts in different urban landscape revival projects. These initiatives, however, we could observe more as interesting creative, but again unsuccessful attempts to create age's old idea of gathering all the knowledge of the world in one space, just with the use of new media.

\section{Creating Memory Theatre in the contemporary time}

Nowadays, many artists, as well as many enthusiasts are inspired with the dream of creating a complete collection of the world 
and gathering it in one space, no matter if it is physical construction, literal creation or virtual project. The variety of these attempts was maybe the best visible at the 55th Biennial Exhibition in Venice when the commissioner Massimiliano Gionni decided to dedicate the whole central exhibition to the dream of memorizing the whole world in one spot. The very name of the exhibition, Encyclopedic Palace, including the whole concept of the Venice Biennale that year, was inspired by the project of an Italian-American artist, Marino Auriti, who conceived his own impossible, imaginary museum: a building that would house all the knowledge of this world. The eternal question of the possibility of gathering all knowledge in one place this time was shifted to the modern world of image, both in real and digital spaces. From this opening work done by Marino Auriti, through different collections and notebooks visualizing attempts to gather not just objects and personal memories, but also the subconscious happenings and emotions, to digital works reliving again Ars Memoria and the temples of knowledge and storages on the net, the whole setting was constructed as a big Cabinet of Wonder of the modern age (Jokanović, 2017b).

Finally, as Gionni also concludes, all these attempts were proven once more to be impossible and utopian, no matter the media they are supported with. Moreover, he adds that it is not any other media, but the human mind that is trying to produce the total image of the world and that is longing for memorizing and explaining conscious as well as subconscious. A world inundated with images, or representations as we know it today is a world of manifesting inner performances through various media. However, the basic medium in which images are created has always been, as Gionni will suggest, the human mind as a kind of encyclopedia, that is, a cabinet of wonder or a castle filled with ideas that an individual tries to emulate (Gionni, 2013).

On the other hand, Michael Mandiberg, an interdisciplinary artist, had a project to print out Wikipedia stressing the enormousness of this digital library or as theoreticians argued: "making a poetic gesture toward the futility of the scale of big data" (Vincent, 2015). However, even illustrating the enormousness of the digital space, this project has also proven to be "a waste of time", 
an attempt doomed to failure when it comes to finishing it, as online Wikipedia was filled with new information already during the printing activities. This example could maybe confirm us once more that it was not a problem of space (as digital space is offering the inconceivable vastness), but of the always missing elements of the collection (Jokanović, 2017a).

Still, these artistic gestures remind us once more that the striving to archive all the knowledge of the world was never separated from creative minds from antiquity to today, as we could see above. The scientific and artistic work, therefore, should still be intervened in the attempt of reaching omniknowledge. Writing about the archival work of artists, Foster Hall will also mark it as "the melancholic, often vertiginous, always incomplete". This author will conclude that archival art and the tendency of artists to make all-encompassing collections and curate them might "emerge out of a similar sense of a failure in cultural memory" (Foster, 2004: 12, 22). Accordingly, being disappointed with the missing elements of history, the Lebanese-American media artist Walid Raad constructed a fictional foundation and a digital archive project called "The Atlas Group" in 1999. It is composed of fabricated historical documents that reconstruct the forgotten history of the Lebanese Civil War (1975-1991), a tragic implosion of the colonial and the Cold War hegemonies implanted in the highly inflammable multiethnic community. "Raad uses the para-index to lure spectators rambling in their broken passion for the real. The para-index creates an urge, a psychological invitation, to an event that takes place in a void between history and memory. Connecting what's missing in history and what lingers in memory, this urge brings forth a redemptive demand for the real buried in our symbolic history" (Choi, 2018: 8).

Following this example, we could conclude that the melancholy of an incomplete collection could be surpassed with the creation of the missing elements of our past. This imaginary archive is therefore a step further from the Imaginary museum suggested by Andre Malraux at the moment when the technological invention of photography was changing the paradigm of collecting and gathering knowledge at one spot. We will therefore suggest that these 
attempts of generation of the missing elements of the past on one hand, and technological development on the other, have brought us to the possibility of a new epistemological turn and potential to finally reach the utopian dream of humankind.

However, we could raise the issue if there is a way out of the explicitly human mind, and if we could find the solution in finally gathering the knowledge of the world not by a human, but with the help of the artificial mind.

Whichever the episteme was in time, a man was trying to gather all the existing elements of the world. However, did he ever, as Raad did in his artistic act, think that the knowledge cannot be all-encompassed if he does not concentrate on those lacking components and the manners of inventing them and completing the collection finally?

\section{Knowing as combining data in the digital episteme}

To know today, in the digital age, means more than ever before, to own all the information in one storage while the new content is often created out of already existing and combined elements. Writing about transmedia narratives in the context of film and television, Aleksandra Milovanović tackles important issues on creating the content today. Informed by Henry Jenkins' notion of convergence culture (Jenkins, 2006), she agrees that, in a virtual culture, old and new mediums coexist, while new content is often composed out of many different already existing narratives.

With the apparition of each new medium, a new way of organizing narratives was emerging. Looking historically at storytelling, it always depended on the technology of narrative id est. narrative specificities of a particular medium. Therefore, one might imagine that future storage, retrieval and sorting technologies, such as those simply and relatively inexpensively provided by computers or Internet servers today, could create new narrative forms. Explaining this, Milovanović recalls a term used by Thomas Elsaesser: database narrative, which is a different system from all previous 
ones in the telling, sequencing, and connecting information to stories. The transformation of the content is consequently moving towards a complementary interconnection of the media, their greater immersiveness, and networking of narrative flows, whose interactive sum will be seen as a new form of a story that emerged from it transmedially. Therefore, digital platforms for the distribution of media texts fulfill the functions of virtual archives and call for participativity - (inter)activity. As virtual media archives, they are "program repositories". Consequently, new platforms for contemporary transmedia narratives still depend on the television because of its vast archive for which they open a "new window" of showing, Milovanović will conclude (Milovanović, 2019: 107).

This theory can be understood much wider than just on the examples of the film and television narratives. A tendency of appropriation and quotation is present in the visual art world and literature as well, while the whole 'post time' implies the use of the past in contemporary time, its' recontextualization and requisitioning. Therefore, a tendency to remember the whole knowledge of the world and store it, for a 'post media' generation used to constant selection of what to consume and how to combine data, is not just a utopian dream but a point of departure for almost every creative/ constructive act.

However, computer science is still bringing many different solutions. While robots and smart technology machines have already replaced many workers in companies, artificial intelligence is substituting workers even in the humanist field. Being as well inspired by observations made by Michel Foucault in The Archaeology of Knowledge that the trends toward continuity and discontinuity in descriptions of historical narratives and philosophy, respectively, are reflections of larger hermeneutic structures that in and of themselves influence knowledge formation, Emily L. Spratt explores the question of the role of image-related data science in our humanistic interpretation of the world. In her lecture, she explains that the artificial intelligence-enhanced search engines have become the predominant mode of knowledge investigation in the last couple of years. 
In this system, the discovery of responses to our every question is facilitated as the vast stores of digital information that we have come to call the data universe are conjured to deliver answers commensurate with our human scale of comprehension. In this digital engagement, it is often assumed that queries are met with complete and reliable answers, and that data is synonymous with empirical validity, despite the frequently changing structure of this mostly unsupervised repository of digital information, which in actuality projects a distortion of the physical world it represents. (Spratt, 2019)

And this is the crucial point. What if artificial intelligence is today capable of providing all the missing elements of a contemporary cabinet of the world? Due to the vast storage of digitized information, a computer is capable of assuming how for example a lost antique pot looked like. It is combining the existing information on other similar objects, their origin, and basic characteristics and providing models which are several times by now proven to be very close to reality or completely the same. Being fascinated with the use of technology and artificial intelligence for the computergenerated art production, in her interview with new media artist Mario Klingeman, Spratt raises the issue if there is the possibility of what machine learning can produce on its own actually opens up the possibility for more horizons of understanding and of knowledge production in general, or it is just as finite in its ability to allow comprehension and discovery as a human is. The artist stresses the importance of the fact that technology is now more than ever before accessible to the wider community and not just scientists, confirming once more the need of combining creative and artistic work, in the same manner these were inseparable before the modern episteme: “(..) technology was suddenly in the hands of people like me and others who were not using the new technology for scientific research, as it traditionally had been used." (Spratt, 2018, p. 37) Even seeing great potential in it, this artist will stress the present limits of technology. Finally, Spratt stresses that: "machines can definitely accelerate the way we acquire knowledge and cover new things, but in a way, the speed at which they can move is 
still defined by how quickly we ourselves can adapt to this kind of knowledge." (Spratt, 2018, p. 38) However, it is the question what will happen with the further development of technology and artificial mind. If, as we already mentioned, the invention of photography provoked the Imaginary museum, is the use of new technology in creating an all-encompassing collection just one step further? Spratt will also ask: "Will the necessity for human interpretation always be there? What happens when we are able to reach a level of artificial general intelligence, or AGI, as some scholars are calling it? What happens when we have a machine that is able to criticize itself and to make a commentary on itself? When a machine is able to philosophically comment upon its own structure of existence, I believe that this would be the ultimate sign of its intelligence" (Spratt, 2018: 38).

Nevertheless, if the interviewed artist, Facebook, and many others use the machine to generate non-existing faces, why wouldn't we believe that the machine could generate all the missing elements of the human past and help in the creation of an all-encompassing knowledge collection?

It is, therefore, necessary to question if we are witnessing a new epistemological turn in which the artificial intelligence engines will become an extended arm of the human mind and quest when it comes to the creation of the final complete collection of the world. Because, if all its missing elements can eventually be found, humankind is definitely facing a great turn.

Consequently, it is interesting that elements of the world that have been stored for ages are now (with the use of new technology and being digitized) becoming key components for machine engines which will fill the holes. Will the total image in the world overwhelmed with images finally be created? Will the melancholic feeling provoked by a never completed collection be overcome? Does to know today mean to own software that knows, while the dream of bringing the knowledge of the world together into one place is becoming possible in the extended and intertwined space of cognition of human and artificial mind? Is the omniknowledge eventually being gathered in the digital space? 


\section{References}

Abt, Dž. (2014) “Poreklo muzeja”. In Mekdonald, Sh. (Ed.), Vodič kroz muzejske studije. Beograd: Clio, pp. 171-200.

Borhes, H.L. (2004) Alef. Beograd: Paideia.

Choi, J. (2018) "Reinventing the archive in the age of digital reproduction: Walid Raad's the Atlas Group", Digital Creativity, vol. 29, pp. 235-248. https://doi.org/10.1080/14626268.2018.1447969

Dalamber, Ž. (1955) Uvodna rasprava u Enciklopediju. Beograd: Kultura, Mala filozofska biblioteka.

Ernst, W. (2013) Digital Memory and the Archive. Minnesota: University of Minnesota Press.

Foster H. (2004) "An Archival Impulse", October No. 110, US: MIT Press, pp. 3-22.

Fuko, M. (1971) Riječi i stvari. Beograd: Nolit.

Gioni, M. (2013) “Is Everything in My Mind?”, Il Palazzo Enciclopedico, The Encyclopedic Palace, Venice: Biennale Arte 2013, Volume I, r. 23, quoting Plato (1669) Ars Magna Sciendi.

Gnjatović, M. (2013) "Practices of the Identity Construction with the Use of Different Media". In Selnes, K., Senyushkina, T. (Eds.) Identity and Collective Memory. Norway Humanist Association: Oslo, pp. 84-94.

Hooper-Greenhill, E. (1992) Museums and Shaping of Knowledge. London, and New York: Routledge

Jenkins, H. (2006) Convergence Culture: Where Old and New Media Collide. New York and London: New York University Press.

Jokanović, M. (2017) Kabineti čudesa u svetu umetnosti - upotreba istorijskih modela muzealizacije u savremenoj umetničkoj praksi, doktorska disertacija. Beograd: Biblioteka Odeljenja za istoriju umetnosti, Filozofski fakultet Univerziteta u Beogradu.

Jokanović M. (2017a) "The Old New Media: Artist Archives in the Digital Age", Media Archeology: memory, media, and culture in the digital age = Medijska arheologija: sećanje, mediji, kultura u digitalno doba, Belgrade: Faculty of Dramatic Arts, pp. 145-155.

Jokanović M. (2017b) "Memory on Cabinets of Wonders in Modern and Contemporary Art", In Poulot D., Stanković, I. (Eds.), Discussing Heritage and Museums: Crossing Paths of France and Serbia, Choice of Articles from the Summer School of Museology Proceedings, Website of HiCSA, Paris. 
Maroević, I. (1993) Uvod u muzeologiju. Zagreb: Zavod za informacijske studije odsjeka za Informacijke znanosti, Filozofski fakultet Sveučilišta u Zagrebu

Matussek, P. (2020) “Inventing Interfaces: Camillo's Memory Theater and the Renaissance of Human-Computer Interaction". In Black C. \& Álvarez M. (Eds.) Renaissance Futurities: Science, Art, Invention. California: University of California Press, pp. 41-65. DOI:10.1525/9780520969513-006

Milovanović, A. (2019) Ka novim medijima. Beograd: Fakultet dramskih umetnosti i Filmski centar Srbije.

Popadić, M. (2015) Vreme prošlo u vremenu sadašnjem - uvod u studije baštine. Beograd: Centar za muzeologiju i heritologiju, Filozofski fakultet Univerziteta u Beogradu.

Spratt, L. E. (2019) Archaeologies of Knowledge for Data Science: A Discourse on Art, Archives, and AI Available at: https://www.f.bg.ac.rs/ files/22032019\%20gostujuce\%20predavanje\%20JE\%20apstrakt. doc (Accessed: November 21st 2019)

Spratt, L. E. (2018) 'Creation, Curation, and Classification: Mario Klingemann and Emily L. Spratt in conversation', XRDS Vol. 24 No. 3, https://xrds.acm.org/archives.cfm?iid=3204480 (Accessed: October 16th 2020)

Yates, F. (1966 - reprinted in 1999) The Art of Memory, Selected Works, Volume III, London and New York: Routledge

Милосављевић-Аулт, А. (2005) 'Студиоло као предмет истраживања у историји уметности и историји колекционарства', Гласник Народної музеја Црне Горе, Цетиње, Нова серија, II књига, стр. 121-145. 


\section{Milena Jokanović}

Odeljenje za istoriju umetnosti, Seminar za muzeologiju i heritologiju, Filozofski fakultet, Univerzitet u Beogradu, Srbija

\section{POSTOJI LI MOGUĆNOST DOSTIZANJA (SVE) ZNANJA U DIGITALNOM PROSTORU?}

Težnja ljudi za nagomilavanjem najrazličitijih predmeta na jedno mesto, kolekcioniranjem čovekovih umotvorina ali i predstavnika svih biljnih i životinjskih vrsta, stara je verovatno koliko i sam čovek. Antički Museion, Aleksandrijska biblioteka, Nojeva barka, teatri memorije, kabineti čudesa, enciklopedije, te brojni savremeni naučni i umetnički projekti - primeri su viševekovnih pokušaja čoveka da okupi sve vrste, sazna i razume Svet i konačno postane njegov suveren. Svaki od ovih pokušaja do sada se pokazao kao neuspešan, koliko god da su zbirke bile brojne i spiskovi beskrajni, uvek bi ostali nedovršeni, nepotpuni, a nepregledni. Ipak, savremeno doba i stalni razvoj informacionih sistema i digitalne humanistike nude potpuno nove načine pohranjivanja i klasifikacije podataka, te nove uvide kako iste upotrebljavati i kombinovati. Digitalne baze podataka koje se danas razvijaju baštine nesamerljive količine predmeta, odnosno informacija, dok veštačka inteligencija uspeva da kreira i one elemente koji su vremenom izgubljeni, te nedostaju. Prateći odnos čoveka prema znanju kroz vreme, a oslanjajući se na epistemološke zaokrete koje sugeriše Mišel Fuko, te istražujući potencijale koje danas nude digitalni prostor i savremena tehnologija, u ovom radu istraživaćemo da li je do nedavno utopijska ideja sakupljanja sveg znanja sveta na jedno mesto danas ipak moguća, kao i da li je odnos prema znanju potpuno promenjen $i$ šta isti predstavlja u „post-vremenu“.

Ključne reči: znanje, kolekcioniranje, episteme, digitalni prostor, veštačka inteligencija 